\title{
The chronotopical nature of identity construction: Case studies of narrative identities of EFL teachers
}

Hosseini Fatemi, Azar

Ferdowsi University of Mashhad, Iran (azar.h.fatemi@ferdowsi.ac.ir)

Pishghadam, Reza

Ferdowsi University of Mashhad, Iran (pishghadam@um.ac.ir)

Hashemi, Mohammad Reza

Ferdowsi University of Mashhad, Iran (smrhir@gmail.com)

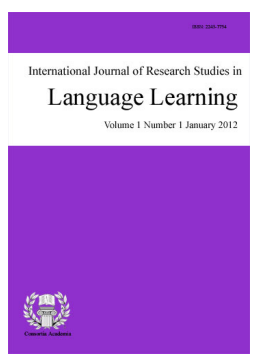

ISSN: 2243-7754 Online ISSN: 2243-7762

OPEN ACCESS

Adel, Seyyed Mohammad Reza

Ferdowsi University of Mashhad, Iran (adelzero@yahoo.co.uk)

\section{Abstract}

This study invoking two key Bakhtinian concepts, chronotope and authoritative/persuasive discourse, tried to show the interplay of identities six EFL teachers assumed through the narrative inquiry. Based on the analysis and coding of the data, four chronotopes were distinguished and termed as first generic chronotope, second generic chronotope, third generic chronotope, and fourth generic chronotope. This study showed that both discourse type and chronotope were key distinguishing factors in teachers' constructions of multiple identities. Teachers were different both in the discourse type and the kind of chronotopes, though the discourse types and the chronotopes were fused together. Some pedagogical implications in regard to teacher identity in the context of language learning were also proposed.

Keywords: Bakhtin; identity construction; narrative identity 


\section{The chronotopical nature of identity construction: Case studies of narrative identities of EFL teachers}

\section{Introduction}

In the present research, we have tried to study teacher identity by using narration as a methodological tool and Bakhtin's ideology as the theoretical inspiration of the study. First, we try to report a few studies on teacher identity, and then we take narration into account to argue that it is a strong tool in investigating identity construction. Next, as teacher identity is theorized in regard to Bakhtin's theory and in particular to two key Bakhtinian concepts, chronotope and authoritative/persuasive discourse, we will clarify the concepts. Some other concepts like utterance and genre which are linked to the dialogic theory are also explained. Then, based on the review and the theoretical framework, we will pose our relevant research questions.

\section{Review of literature}

\subsection{Teacher identity and narration}

The importance of teacher identity has been highlighted through various studies in the realm of applied linguistics in a variety of different ways (Alsup, 2006; Flores \& Day, 2006; Hunt, 2006; Mitchell \& Weber, 1999; Pishghadam \& Sadeghi, 2011; Pishghadam \& Shirmohammadi, 2012). Narrative inquiry has been reported to be a powerful method of teacher identity analysis (Connelly \& Clandinin, 1999; Sfard \& Prusak, 2005; Søreide, 2006). Bakhtin's theory has also been applied in the context of language teaching and education (Buty \& Mortimer, 2008; Cohen, 2008; Menard-Warwick, 2011; Pishghadam, Hashemi, \& Adel, 2010). In his critical essay, Matusov (2007) reviews two recent edited collections relevant to applying Bakhtin's scholarship in the field of education: Arnetha F. Ball and Sarah Warshauer Freedman's Bakhtinian Perspectives on Language, Literacy, and Learning and Bonny Norton and Kelleen Toohey's Critical Pedagogies and Language Learning. He problematizes whether Bakhtin's notions of dialogism and internally persuasive discourse are compatible with institutionalized education. In conclusion, he raises some questions: "Can pedagogy be truly dialogical (that is, within the regime of internally persuasive critical discourse)? Should it be? And how much internally persuasive critical discourse is possible and desirable in education?" (pp. 236-7)

Few studies, however, have considered the roles of discourse in Bakhtin's sense and narratives together. Some researchers have shown the relationship, which depending on different contexts is complex, between narrations and revealing identities (Pavlenko, 2002; Schiffrin, 1996, 2006) and there are some studies done in the field of narrative identities (Johnston, 1997; Norton \& Early, 2011; Razfar, 2012; Tsui, 2007). In narration, one may reveal multiple identities. As Ricoeur (1988, p. 247) puts it "narrative identity constructs a sense of self-sameness, continuity and character in the plot of the story a person tells about him- or herself. The story becomes that person's actual history". In the same vein, Schiffrin (1996, p. 170) notes that "our identities as social beings emerge as we construct our own individual experiences as a way to position ourselves in relation to social and cultural expectations". If someone asks you who you are, you may disclose one of your identity, but as a social being, if you want to tell about your history, you may release many of your ideas. When telling stories, we convey to others a sense of who we are, of our beliefs and values (Bastos \& Oliveria, 2006).

As Varghese, Morgan, Johnston, \& Johnson (2005) note, teacher identity has been theorized in regard to different theories such as Tajfel's (1978) social identity theory, Lave and Wenger's (1991) theory of situated learning, and Simon's (1995) concept of the image-text. We have taken Bakhtin's dialogism into account for the theoretical relation of identity analysis. As Vitanova (2005) notes dialogism is central to identity development, which occurs as individuals engage in dialog with discourses from their environment, and appropriate them for 
The chronotopical nature of identity construction: Case studies of narrative identities of EFL teachers

their own purposes. So, in what follows, we try to clarify Bakhtin's theory briefly particularly the major concepts of chronotope, genre, and authoritative and persuasive discourse which are the center of the present research theoretical discussion.

\subsection{Bakhtin and dialogism}

Bakhtin (1895-1975) is a social constructivist Russian thinker. Bakhtin's ideas are greatly influenced by 18-19th century German philosophy (in particular Kant, Cassirer, Heidegger, and Nietzche), and the Marburg School, and comprise the interplay of neo-Kantian inspired Russian orthodox morality, and Cassirean philosophy of the symbol; they are in reaction against Marxist-Leninist ideologies of dialectical materialism and earlier Hegelian dialectics (Brandist, 1999; Cote, 2000). In Hegelian dialectics, the persuasive discourses are rejected in favor of authoritative discourses. Applying such an approach to education, in Emerson's words (1997, p. 70), is that "in order to make sense out of change, one must analyze it into a system. Whatever does not fit the system is relegated to the realm of spontaneity or anarchy - to be cast out, brought under control or annihilated". On the contrary, the essence of dialogism is the identification within and without. As Bakhtin puts it: "we open the boundaries when we "identify" ourselves with the hero and experience his life from within: and we close them again when we consummate him aesthetically from without" (Bakhtin, 1990, p. 91).

Bakhtin's philosophy was influential and drawn upon the works of Dostoevsky (Bakhtin, 1973), Rabelais (Bakhtin, 1968), and linked with his political location in Marxist Russia (Emerson, 1997). Bakhtin, analyzing Dostoevsky's works, expands the concept of dialogism and takes the Dostoevskian loophole as a central nature of dialogue. In Clark and Holquist's words (1984), "dialogism is the metaphysics of the loophole. And although the loophole is the source of frustration, pain and danger we must confront the world so dominated by the unknowable, it is also the necessary precondition for any freedom we may know" (p. 347).

Among the various concepts of dialogism, chronotope is a central concept. It seems that Bakhtin (1981, p. 84) has borrowed the term chronotope from Einstein's Theory of Relativity, but Holquist (1994, p. 153) notes that Bakhtin's use of the term dates back to Aleksey Ukhtomsky's lecture on the chronotope in biology in 1925. Bakhtin (1981) defines chronotope as "the intrinsic connectedness of temporal and spatial relationships that are artistically expressed in literature" (p. 84). Bakhtin used the term chronotope to show that time and space exists as far as there is a change. It is change that gives value to these two concepts. He (p. 84) further notes that "time, as it were, thickens, takes on flesh, becomes artistically visible; likewise, space becomes charged and responsive to the movements of time, plot and history. This intersection of axes and fusion of indicators characterizes the artistic chronotope". Though he worked on literary texts, and he applied the concept literary, but he further notes that chronotopes characterized non-literary texts and contexts as well: "every entry into the sphere of meaning is accomplished only through the gates of the chronotope" (p. 258). On the wider application of chronotope to other texts, Morson and Emerson (1990, p. 368) note that "the concept has much broader applicability and does not define a strictly literary phenomenon". They further maintain that "all contexts are shaped fundamentally by the kind of time and space that operate within them" (Morson \& Emerson, 1990, p. 367). They (1990, p. 371) give a definition of chronotope in culture as a "field of historical, biographical and social relations".

Chronotope has no meaning in itself. In Holquist's words (1994), "like the utterance, chronotope is not a term that can be invoked in general. It must be a chronotope of someone for someone about someone. It is ineluctably tied to someone who is in a situation" (Holquist 1994, p. 151). So, chronotope in its narrow or wide sense bears meaning and meaning is expressed through words. For Bakhtin, a word is a world. He declares that, "an individual's becoming, an ideological process, is characterized precisely by a sharp gap between... the authoritative word (religious, political, moral; the word of a father, of adults and of teachers, etc.) that does not know internal persuasiveness, and... the internally persuasive word that is denied all privilege, backed up by no authority at all, and is frequently not even acknowledged in society" (Bakhtin, 1981, p. 342). Unlike dialogic language, "the authoritative word or discourse is monologic, distant from context, unanswerable, and embodies different sources of authority (tradition, generally accepted truths, official lines). It is an imposition, in the sense 
that it demands that we acknowledge it, that we make it our own; it binds us quite independent of any power it might have to persuade us internally; we encounter it with its authority already fused into it. The authoritative word is located in a distanced zone, organically connected with a past that is felt to be hierarchically higher... It is therefore not a question of choosing it from among other possible discourses that are its equal" (p. 342). In the words of Holquist "undialogized language is authoritative or absolute" (1994, pp. 426-7). Authoritative discourses or what Delpit (1995), Gee (1992, 1996), and others have termed "the languages of power" encode "cultural capital" (Bordieu \& Passeron, 1977).

Bakhtin (1981) notes that the creativeness of an independent internally persuasive discourse lies precisely "in the fact that such a word awakens an independent words, that it organizes masses of our words within" (p. 343), words that come from our understandings on the events, actors, and relationships in our everyday lives. Bakhtin maintains that "one's own discourse is gradually and slowly wrought out of others, words that have been acknowledged and assimilated... in everyday rounds of our consciousness, the internally persuasive word is half ours and half someone else's" (Bakhtin, 1981, p. 345). "The semantic structure of an internally persuasive discourse is not finite, it is open; in each of the new contexts that dialogize it, and this discourse is able to reveal ever newer ways to mean" (Bakhtin, 1981, p. 346).

Instead of word, Bakhtin prefers to use utterance as the realization of language. He (1986) notes that: Any concrete utterance is a link in the chain of speech communication of a particular sphere. The very boundaries of the utterance are determined by a change of speech subjects. Utterances are not indifferent to one another, and are not self-sufficient; they are aware of and mutually reflect one another. These mutual reflections determine their character. Each utterance is filled with echoes and reverberations of other utterances to which it is related by the communality of the sphere of speech communication (p.91).

He makes a link between utterance and genre as one of his theoretical concepts: "Each sphere in which language is used develops its own relatively stable types of these utterances. These we may call speech genres" (Bakhtin, 1986, p. 60). He further mentions that: Utterances and their types, that is, speech genres, are the drive belts from the history of society to the history of language. There is not a single new phenomenon (phonetic, lexical, or grammatical) that can enter the system of language without having traversed the long and complicated path of generic-stylistic testing and modification (Bakhtin, 1986, p. 65).

In regard to the relation of utterance and genre, he further notes that without genres, speech communication is almost impossible: We learn to cast our speech in generic forms and, when hearing other's speech, we guess its genre from the very first words; we predict a certain length ... and a certain compositional structure; we foresee the end; that is, from the very beginning we have a sense of the speech whole, which is only later, differentiated during the speech process. If speech genres did not exist and we had not mastered them, if we had to originate them during the speech process and construct each utterance at will for the first time, speech communication would be almost impossible (Bakhtin, 1986, p. 79).

Genres in Bakhtin's idea are not detached from our consciousness: We speak only in definite speech genres, that is, all our utterances have definite relatively stable typical forms of construction of the whole... We assimilate forms of language only in forms of utterances and in conjunction with these forms. The forms of language and the typical forms of utterances, that is, speech genres, enter our experience and our consciousness together and in close connection with one another (Bakhtin 1981, p. 78).

Genres are considered as simple and complex. Simple genres have "an immediate relation to actual reality and to the real utterances of others, e.g. short rejoinders of daily dialogue, everyday narration, the brief standard military command" (1981, p. 60). Complex genres are "the elaborate and detailed order, the fairly variegated repertoire of business documents, the diverse forms of scientific statements and all literary genres (from the proverb to the multivolume novel)" (1981, p. 60). Chronotope was introduced by Bakhtin for the complex genres. 
The chronotopical nature of identity construction: Case studies of narrative identities of EFL teachers

Using utterance, genre, chronotope, and authoritative/persuasive discourse and many other related concepts, which are not our concern in this paper, Bakhtin tries to show language as dynamic and meaning in the ever process of becoming. Based on these concepts, we try to use narration to answer the following research questions:

1. What are the prototypical generic chronotopes in the narratives of EFL private language school teachers shaping and reshaping their multiple identities?

2. What are the possible factors involved in generating the generic chronotopes in the narratives of EFL private language school teachers?

3. Are teachers' chronotopes authoritatively constructed or persuasively formed?

4. What are the possible relationships between discourse types and the generic chronotopes in constructing teachers' multiple identities?

\section{Methodology: Subjects and setting}

Six representative EFL teachers from a private institution were chosen as our cases to be studied. A private institution was chosen as site of our struggle because in such settings there is little control in the choice of teachers and the government has little supervision on such settings. Most of the students who choose English as their major in the University are nurtured in such private schools.

To select some representative teachers from these private schools, we investigated almost all private language schools in Mashhad (Iran) and found that the private institute of Forough is one of the oldest school in this area, registered as No. 1623 in 1369 with the permission of Department of Education, Khorasan Razavi province. The center having more than 130 academic and administrative personnel with a long history of education and providing a unique system for different levels has been able to attract a wide range of people interested in different languages (English, German, Russian, French, Italian and Spanish). The institute and related centers have been given Management and Planning permit No. 1803.198157 and also received a certificate of iso9001-2008 quality management in education No. 08-Q-01095-TIC. It holds classes for all levels from elementary to advanced and even some preparatory classes for MA and PhD levels. In 2004, Forough institute obtained IELTS International test certification from the British council. The Institute has been the location of holding this test for several years in the East.

The teachers chosen were 3 males and 3 females. They were all provided teacher insurance for the job security. Some of these teachers' information which is related to our title of investigation on teacher's identity is given below. The information extracted in the process of interviews both oral and written partly shows the identities of our targeted teachers which will be discussed in the following sections.

\subsection{Case 1 (Hedyeh)}

Her name was Hedyeh. She was born in Mashhad. She was 29 years old. She was married and had no children. Her husband had a free job. She had started learning English when she was 5 years old. Her native language was Persian and she just knew English as her foreign language. She had a BA and an MA in TEFOL. She had a full time job as an English teacher in Forough institute for 5 years. She was a part-time teacher in some other institutes and Universities as well. She had taken part in an English international conference as well. And she had in her CV one article (Grammar learning) printed in an Asian journal, which was extracted from her MA thesis. In all, she had about 10 years of formal experience of teaching English to students of various proficiency levels from elementary to University students. She was teaching an average of 30 hours in a week. She had no private English classes. 


\subsection{Case 2 (Khatereh)}

Her name was Khatereh. She was born in Mashhad. She was 48 years old. She was married and had 3 children, two girls and a boy. Her husband was a nurse in the hospital. Her native language was Persian and she just knew English as her foreign language. She had a BA and an MA in TEFOL. She had a full time job as an English teacher in Forough institute for 7 years. She was a part-time teacher in some other institutes and Universities as well. She had been supervising an English Kindergarten (Azadeh) for 1 year and an English institute (Nezami) in Mashhad for 4 years. In all, she had about 13 years of formal experience of teaching English to students of various proficiency levels from elementary to University students. She was teaching an average of 70 hours in a week including her private English classes.

\subsection{Case 3 (Nazanin)}

Her name was Nazanin. She was born in Mashhad. She was 38 years old. She was married and had a boy. Her husband was a teacher teaching Persian literature. She had started learning English when she was 5 or 6 years old. Her native language was Persian and she just knew English as her foreign language. She had a BA in English literature. She was living in Mashahd where she was a full time English teacher in Forough institute for 9 years. She had been a part-time teacher in some other institutes and she had been a full time translator in a company for 9 years. She was still doing this translation job as part time. In all, she had about 15 years of formal experience of teaching English to students of various proficiency levels from elementary to advanced students. She was teaching an average of 50 hours in a week and 25 hours of translation.

\subsection{Case 4 (Mohammad):}

His name was Mohammad. He was 29 years old. He was married and had a little girl. His wife was a householder. He had started learning English when he was in the guidance school at the age of 12. His native language was Persian and he just knew English as his foreign language. He had a BA in English literature. He was living in Mashhad where he was a full time English teacher in Forough institute for 5 years. He had been a part-time teacher in some other institutes as well. In all, he had about 11 years of formal experience of teaching English to students of various proficiency levels from elementary to advanced levels. He was teaching an average of 70 hours in a week.

\subsection{Case 5 (Farhad)}

His name was Farhad. He was born in Tehran. He was 28 years old. He was married and had no children. His wife was a householder. He had started learning English when he was 4 years old. His native language was Persian and he just knew English as his foreign language, but he was trying to learn French too. He had a BA in English literature. He was living in Mashahd where he was a full time English teacher in Forough institute for 3 years. He had been a part-time teacher in some other institutes too. In all, he had about 6 years' experience of teaching English to students of various proficiency levels from elementary to advanced. He was teaching an average of 40 hours in a week. He had many private English classes.

\subsection{Case 6 (Shahriyar)}

His name was Shahriyar. He was born in Mashhad. He was 30 years old. He was single. He had started learning English when he was in the guidance school. His native language was Persian and he just knew English as his foreign language. He had a BA in English literature. He was living in Mashahd where he was a full time English teacher in Forough institute for 8 years. He had been a part-time teacher in some other institutes too. He also had private English classes. In all, he had about 12 years' experience of teaching English to students of various proficiency levels from elementary to advance. He was teaching an average of 65 hours in a week. 


\section{Instrumentation and procedure}

The data analyzed and the results presented in this article are part of a larger project that aimed to describe the interaction of teachers and textbooks' roles on the identity construction of some private language school learners. Our whole data collection took a long time from 23 September 2010 to 30 September 2011. The learners were six male and female English learners who were studied for three semesters. The learners of this institution had a different teacher each semester, but sometimes they had the same teacher who was teaching them for two consecutive semesters, though rarely this happened. In all, these learners experienced six teachers in these three semesters. The male learners had a male teacher and the females had female teachers. Therefore, the method of teacher selection depended on our learners as our cases. In the large and extended project, we met our cases for about four semesters but we observed each teacher for one semester, though we had contacts with them during the project as well. We observed one semester as a preparatory stage. During our observation, we had many contacts with the teachers through phones, teachers' notes, formal and informal interviews, meeting them in their homes, in the car, in the office and outside the classes. We met them in their classes and we arranged to meet them for interviews in advance. They all were volunteered to take part in the interviews and had signed the written letter which asked them to read the purposes of our research and if possible cooperate with us during the project.

As the purpose of the interviews was reconstructing teachers' identities and not understanding the proficiency level of the teachers, the interviews were held both in English and Persian. The Persian interviews then were translated into English. We were given permission to tape the interviews and they signed an agreement that allowed us to use the transcribed material in our project. To observe codes of ethics in research, however, the names are fictitious. The questions were open ended questions and let them talk freely about their English experience, their choices, and whatever they liked which was related to their job. In our targeted larger project, however, we asked them many other structured questions regarding some types of identities. But, the focus in the present article is to look at the narratives to investigate the relation of discourse types and chronotopes in the teachers' stories. Due to the large corpus of our data (about 30 hours formal and informal interviews with teachers), we tried to extract only the parts related to our proposed chronotopes and discourse types.

\section{Results and discussion}

After reading the whole data and extracting the chronotopes and the discourse types, they were divided into four chronotopes and two kinds of discourse. Our unit of analysis was discourse. Bakhtin's theoretical framework and all the related terminologies show that the unit of analysis should be the whole context, and not discrete units such as word or phrases. Oliva (2000), Matusov (2007) and Tihanov (2000) advocating the dialogical methodology also reject the analysis of one discreet unit of analysis.

In order to come to a common consensus of the chronotopes' numbers, three independent MA (two) and $\mathrm{PhD}$ (one) raters read the data and marked the saliency of the chronotopes' numbers. The researchers also verified the data in an iterative manner and tested these chronotopes and discourse types with the whole data. The chronotopes were marked as ordinal numbers (first, second, etc.) and it was due to our inspiration of our theoretical framework. In Bakhtin's constructivist theory, discourse is open ended and there may be several other chronotopes emerging in the course of time and in different contexts resulting in the ever changing of the identities.

The first chronotope was named first generic chronotope which showed the simultaneity of time and place change from birth to 10. This period was considered as the first division because we aimed to investigate the salient changes in the course of teachers' identity development in regard to the English language. The age of ten was considered as the final year as it is a transitory stage when the individuals enter the secondary or guidance school. In Iran usually children go to the primary school at the age of 6 and they enter the secondary school at the age of 10. Children also may have pre-elementary schools as kindergarten for 1 or 2 years before going to 
their first class in the primary school years. The next chronotope was named second generic chronotope from ages 11 to 13 and 14 to 17 . This is when children usually enter secondary school and at the age of 14 after 3 years, they enter high school. They study four years in the high school and then enter university and choose their favorite majors. So, the second generic chronotope includes both the secondary school and high school period. Third generic chronotope was our third category extending from the beginning of the university years (18) to the end (21) which extends four years. And our last category was called fourth generic chronotope which is defined as the teaching experience years of these teachers extending from 22 to 48 . The age of 48 was considered as our deadline as it is the age of one of our cases.

We don't know what will happen later in the lives of these teachers. The chronotopes may happen at other historical times as well. This is exactly the dynamic nature of the dialogical theory of Bakhtin. Our categorization is dialogic and transformative and based on our data and also linked to the educational system of Iran. We are not going to take into account the cognitive consideration as our model is invoked by the socio-cultural theory of Bakhtin.

\section{Table 1}

A socio-cultural model of identities construction based on Bakhtin's dialogic theory

\begin{tabular}{cllc}
\hline Numbers & \multicolumn{1}{c}{ Chronotopes } & \multicolumn{1}{c}{ Discourse types } & Length of time (Years) \\
\hline 1 & First generic chronotope & Authoritative/Persuasive & $0-10$ \\
2 & Second generic chronotope & Authoritative/Persuasive & $11-13 ; 14-17$ \\
3 & Third generic chronotope & Authoritative/Persuasive & $18-21$ \\
4 & Fourth generic chronotope & Authoritative/Persuasive & $22-48$ \\
\hline
\end{tabular}

The analysis of teachers' data shows many chronotopes along with factors which are responsible for possible changes, which gives value to the meaning of these chronotopes. These factors include the father, the university entrance exam, teachers, the institute manager, books, and friends with many other possible factors which may not have been reconstructed. These chronotopes are critical and start a new life for the teachers. Each of them can be considered as a "chronotope of threshold", as "places where crisis events occur, the falls, resurrections, renewals, and epiphanies, decisions that determine the whole life of a person" (Bakhtin, 1981, p. 248).

In what follows, we try to show the reconstruction of teachers' chronotopes, present the factors involved in generating different chronotopes, clarify the discourse type teachers showed and explain the interconnectedness of discourse and chronotopes.

\subsection{Case 1 (Hedyeh)}

For Hedyeh, the role of the father plays an important factor in determining the salient generic chronotope with a blend of authoritative and persuasive discourses. Here are some extracts:

"Ok. My father is a retired police officer and is now working in a real estate agency. My mom is a housewife."

"My father was very kind to register me in English classes when I was 5."

"I went to [Bahar] institute which was the first English Institute in Mashhad."

A salient chronotope happens in this early stage of her life, which we have called first generic chronotope. It is her father's role who "register"s her in an English institute. Though he has been a "police officer", she uses the adjective "kind" for her father to probably show that she has liked to be registered in that institution. At this point of the chronotope, it seems that she is internally persuaded and there is no evident authority of the father. There are some other traces in other parts of her narratives which support this argument: 
The chronotopical nature of identity construction: Case studies of narrative identities of EFL teachers

"[My father] cared about education very much; he persuaded us to continue our studies and so registered me and my older brother and sister in English classes".

She also continues this love for the English language:

"So I continued to study English till the end of the guidance school. When I went to high school, I got my English diploma and I always got the top scores in the English exams. So my English teachers let me do the exercises when they were away."

In the remaining chapters of her story, we see a clash of other chronotopes:

"I studied FCE courses and then I wanted to go to university. My major at high school was mathematics and I loved it. I got high grades and I still have the books of high school. But when I studied pre-university, there weren't as much extra classes and books for admitting in university. I participated in math group in public university entrance exam, and in foreign languages group of private university. I was not admitted in public university, so I decided to study English at private university of Torbat (a city). I liked English but..."

"But you preferred to study math?"

"Yes, it was my goal".

"Pure mathematics?"

"No, the branches like computer engineering or civil engineering but it was my destiny to study English. I liked English, too but not as my major in university".

This extract which happens at the end of what we have called second generic chronotope is another salient change in the history of identity changes of this teacher. This chronotope plays a salient role in shaping the identities of this teacher which is fused together into a clash of discourses. The entrance exam acts as an authoritative discourse preventing her persuasive decision and creating a turning point for her identity formation. She can no longer define herself as someone who belongs to the mathematic community and when asked who she is, she should define herself belonging to the teaching community. In this genre, the interaction of identity and chronotope is evident and inseparable. The analysis of other parts of her narrative does not show any prototypical change.

\subsection{Case 2 (Khatereh)}

The analysis of the whole data of case 2 showed that there were some missing chronotopes in her narratives, but the salient generic chronotope which made her go to the teaching community was her failure in the entrance exam. She failed the exam and she left everything and after 15 years she came back thinking about a career. The trigger was her own financial decision which encouraged her to choose it. This salient generic chronotope carried the flame of internal persuasion a long time after her teaching experiences. She could get stability and could define her "professional self" as stable. However, there were some instances showing some signs of split selves as well. Following are two prototypical chronotopes in the narrative of case 2.

"I remember that there were original books and they were really nice, named Peter \& Jane. There were pretty and interesting pictures and short sentences in them. There were some extracurricular classes that I was taking part in. In junior high school, I was the top student. After that I started to go to the English classes in an institution. I finished the English grammar part but I didn't follow the conversation skills. I thought I didn't need it because at that time, the grammar was the most important part in English lesson. But now the speaking part is the most important. And I didn't go to English classes after I got my Diploma. My field was science in high school. So I preferred to continue my education in Medical or Dentistry field. I had many 
dreams but I couldn't reach them. 15 years later I felt that I had a shortage in my life and it was studying. Then I chose English language and I did it. I really felt that I loved English, but I knew it was difficult for me. I was absent for 15 years."

"I thought I don't need to study English at the university. I tried to reach some better field like medical. Finally I decided to study English seriously and it longed 1 or 2 years."

"I tried and finally I could enter Azad University of Mashhad."

"Did you get your BA?"

"Yes and 3 years later I was admitted in Payame Noor University of Tehran and I got my MA there."

The analysis of her whole data shows that these two chronotopes are the prototypical ones in constructing her identities. She is the oldest one and this change has happened late in her life. We can imply that identities are constructing in the cycle of life and though it is unpredictable, identities may be deconstructed in the passage of time.

There were some gaps or missing generic chronotopes in the narratives of this teacher particularly those 15 years. We asked her about it but she refused to answer and we didn't want to force her to reply. These gaps may fall into the "hidden selves" category. There are, however, some instances which reveal some moments of these hidden selves:

"Well, before choosing this job when I was young I used to do work of art, weaving and even painting .These things are related to creativity."

\subsection{Case 3 (Nazanin)}

The first generic salient chronotope taking place in the life of this teacher is related to her earlier life time when her father persuaded her to study English. The discourse type of her first generic chronotope is persuasion and the remaining narrative also validates this discourse type. The next identity development instance of this teacher is supported by her "good" teachers who had very effective roles on her identities. This is related to her second generic chronotope, her secondary and high school period. Following are some extracts showing her two prototypical chronotopes:

"I have actually inherited this job."

"Hmm. Ok".

"Because my father's field of study is the same as mine. He studied English language and literature."

"Really?"

"And from the age 5 or 6 my father used to teach me the book 'listen and learn', have you heard Sandy-Sue?"

"When I was 5 or 6 we learned the very elementary book. From then on I got interested in English. Then I learned the rest in Secondary school and High school."

"In guidance school, we had English course in the first grade of guidance school."

"They were so nice, our professors ... our teachers, they were really nice ... hmm, in guidance school ....Mrs. Mojabr, she used to teach very well. Her teaching was very good... very 
The chronotopical nature of identity construction: Case studies of narrative identities of EFL teachers

reflectively. She used to teach very sincerely. and in high school as well, Mrs. Sanjari was there ... she was a very good teacher. I had very good teachers."

"In high school?"

"High school ... yes .... The first three years of high school Mrs. Sanjari was our teacher ... in the Fourth year there was another teacher, whose name I don't remember. We had good teachers, they were very effective."

\subsection{Case 4 (Mohammad)}

There is no first or second or third generic chronotopes in the narrative of this teacher. He was supported by his father to continue his education to enter the university. He has not been a very successful high school student. Not remembering the early chronotopes, he did not experience a burning desire to learn English in the secondary (guidance) or high school, though he had started learning English since he was a guidance school student. Then, he enters the university and chooses English as his major as he could not choose other major due to his score in the entrance exam. He didn't mention that he loved English or any other favorite major to choose after high school. He tried to learn English at this time and after his graduation he applied for a job in a private institute. He tried to learn English more while he was teaching in the institute. It was during this teaching period that he slowly began to love her major and the analysis of his whole data shows this. We have called his prototypical chronotope fourth generic chronotope for that matter. He tried to love his profession and he was teaching energetically. Here are a few extracts out of his whole data:

"I don't clearly recollect the high school period, there was one teacher who was really strict; he did care and was tough on students. Anyway I don't actually remember their names, they were not satisfactory though. I don't exactly remember the high school period as well, except one or two whose names have been slipped my mind."

"I studied mathematics at high school. I was not good at that. I didn't like other subjects. It was not important for me."

"What happened in the choice of your major?"

"Nothing in particular; I didn't study for the entrance exam. I went to military service and after two years I came back and thought about a job. I went to study English at Azad university. I didn't study much. I was accepted there."

There are no influential memories from his second generic chronotope:

"I'm not satisfied with the whole educational system, as I mentioned last session. Those who are to teach a course are not qualified in that field at all. For example, an English teacher teaches mathematics or the other way around. They don't have a substantial knowledge about the subject or they are tired and bored, maybe their mind is occupied, so they don't show quality in their job. They usually tend to tell memories and avoid teaching."

"And in the university?"

"I believe in universities nothing is really taught. You should look for knowledge yourself. As inferred when a professor comes, due to the atmosphere, he doesn't care about students to teach them. A student himself should look for it. For example, he must ask about the material and sources. The professor doesn't have a role in teaching." 
First generic chronotope is the prototypical chronotope of this teacher. The discourse type is internally persuasive and it continues for a long time. The analysis of his whole data shows no remarkable happenings in the second or third generic chronotopes. There seem to be more stability and support of that first desire and persuasion in following the English language. In the fourth generic chronotope, however, there seem to be instability and signs of "split selves" and a desire to change his job. It seems that he does like English for communication and not as a profession. Here are some parts of his narrative:

"Since I was a little boy, 6 years old. I was very interested in English, you know, of course, you know, perhaps it was because of a trip I had to Mashhad, you know, my mum comes from Mashhad, although we are living in Tehran right now, and you know, we frequently used to come, to go to Mashhad, and on the way, in one of the trips, you know, my mum used to take the whole cabin, reserved it, and ok, there was... there came someone who was looking for an empty place, and she was a lady, and you know, my mum, warmly greeted her and said come in and you know, she, she realized that I was working with some English words on a paper, just, you know, she started praising me warmly and said, O, honey, do you know English? I said no, but I love to, you know, like a little childish, the way of speaking and she pleased me so warmly, her warmth was so, I felt she loved me, It all started from that place and later on I got more interested in learning English and I asked my mum to send me to an English class. I think that was my first love too".

"As I told you before, I was really mad to follow English and another person, who pushed me forward, was, you know, [laughing] was a Miss. She was also very charming and beautiful, you know, but I was a teenage, I had no lust for her, you know, She had a very spiritual influence on me."

\subsection{Case 6 (Shahriyar)}

He had no prominent first or second generic chronotopes. Somehow, he is similar to our fourth case in these periods. He started learning English at secondary school. He had no goal to continue his education and therefore, the entrance exam was neither a block for him to prevent him from his desires nor a prototypical chronotope to change his identities in one way or another. The main chronotope happened when he was studying in the university. The discourse type associated with this chronotope is persuasion. He learned English by self-study though he was learning it in the university because he was not satisfied with the whole system. Following are a few extracts:

"No one in my family encouraged me to learn English. I started learning English when I was at secondary school, grade one, you know. I liked English but not very much."

"I don't remember my secondary school teachers and how they taught. English was a common subject among other subjects to me. In high school, I studied experimental science as my major. I didn't want to become a Doc. or somebody else. I hadn't a strong urge to study and in the entrance exam I was not successful. I went to military service. When I came back, the easiest way for me to choose a major was going to Azad University. And I chose English for no good reason. When I started learning and learned how to speak English, I found that I love English. In fact, I love to speak English."

"It was during my university period, I went to an institute to start teaching. It was difficult for me how to manage the class, but now it's interesting. The start of my love for English and my job as a teacher was my university period." 
The chronotopical nature of identity construction: Case studies of narrative identities of EFL teachers

"No, I'm not satisfied of my professor in the university. I learned English myself through listening, watching films, teaching, etc."

To answer our research questions more clearly, the data is summarized in the following Table (see Table 2).

Table 2

The generic chronotopes, factors, and discourse types of EFL private language school teachers

\begin{tabular}{lllll}
\hline Case No & Gender & \multicolumn{1}{c}{ Chronotopes } & \multicolumn{1}{c}{ Factors } & Discourse types \\
\hline 1 & Female & First generic chronotope & Parent (father) & Persuasive \\
& & Second generic chronotope & Entrance Exam & Authoritative \\
\hline 2 & Female & Second generic chronotope & Entrance Exam & Authoritative \\
& & Fourth generic chronotope & Self-decision & Persuasive \\
\hline 3 & Female & First generic chronotope & Parent (father) & Persuasive \\
& & Second generic chronotope & Teachers & Persuasive \\
\hline 4 & Male & Fourth generic chronotope & Self-decision & Persuasive \\
\hline 5 & Male & First generic chronotope & A woman & Persuasive \\
\hline 6 & Male & Third generic chronotope & Self-decision & Persuasive \\
\hline
\end{tabular}

The results show that all teachers have experienced certain kinds of chronotopes, which are different in some respects. All females have come across two kinds of generic chronotopes and all the males have experienced just one prototypical generic chronotope. We cannot simply conclude which chronotopes deserve more attention. There are some reasons behind this conclusion. First, we have a small number of populations and the generalizabaility of case study results are always argumentative. Second, even in these cases, there is variability among the kinds of chronotopes and there is no frequency of a particular chronotope, except the third generic chronotope which has happened just once for our sixth case. This may show that chronotopes happening prior to this chronotope may be more important in the construction of teachers' identities. Third, based on and inspired by our dynamic theory of dialogism, even with a large population, we are not sure that the frequent chronotopes should deserve more attention. In other words, if, for example, the first generic chronotope is the most frequent one, we may not be allowed to conclude that the earlier periods of time in the life of teachers are more important that the later periods, because based on dialogism, in the remaining course of time, we may have some prototypical chronotopes which may emerge and deconstruct the identities of the teachers. Two instances are our second and fourth cases in which they experienced that change very late in their life.

Generating chronotopes without considering the factors behind them is not so much fruitful. The analysis of the narratives in all the cases showed many factors involved but the prototypical factors which the teachers highlighted were parents, entrance exam, self-decision, teachers, and a woman. Chronotopes show the time and place of identity construction or the "knots of narratives". In Bakhtin's (1981, p. 250) words, the chronotope is the "place where the knots of narrative are tied and untied". So, the chronotopes determine turning points which are materialized in different contexts. The relation of these chronotopes and identities are the construction and reconstruction of these multiple identities which are tied and untied happening in different contexts.

The factors also show the reasons behind their construction. These factors are worthy to consider as they are responsible for the identity construction. Considering chronotopes and factors without their link to the discourse type may not reveal the fact that identities may find stability or instability depending on the discourse type they are imbued with. For Bakhtin, a discourse which is authoritative is decontextualized and remains to be added to other voices. It is an imposition from without and not within. In the second generic chronotope of our first and second cases, entrance exam acts as an authoritative factor defining these teachers to be who they are by force. This is cyclic, of course, and it be replaced by some other "centrifugal and centripetal forces". An internally persuasive discourse, on the other hand, is the one which is acknowledged by Bakhtin and is open and waiting to "reveal ever newer ways to mean". As Table 2 shows, most of the identities are not imposed (cases 2 (fourth 
generic chronotope), 4 and 6 . In other cases (cases $1 \& 3$, (first generic chronotope) and 5, such a choice have been offered and persuasively accepted by the teachers, or in Bakhtin's sense, it "is half ours and half someone else's". Therefore, all these chronotopes, factors, and discourse types are fused together and change in one may have cyclic effects in the others.

\section{Concluding remarks}

Identity is a complex issue and through the lens of narrative inquiry, we were going to see boundaries or the turning points of identity construction of these EFL teachers. In other words, there were some moments in some places, or in Bakhtin's words, chronotopes, which brought about changes in the identities of teachers making them act in one or the other way. These chronotopes carried a kind of discourse which was either authoritative or persuasive which in turn made the discourse cyclic. The discourse types and the chronotopes were fused together acting and reacting inseparably.

Bakhtin's theory is a fruitful tool of investigation of teacher identity as it is a viable theory and lets researchers not to jump to some static conclusions. It gives us an understanding that identity is in the ever process of becoming and teachers are changing and experiencing several chronotopes. It helps to know and help teachers, syllabus designers, and policy makers know that there is a system of power in the teachers' discourses, within institutions and in the whole society and these are all interconnected. The theory also gives us an understanding why teachers may act in different ways. Bakhtin (1981, p. 115) talks of the motif of transformation, which shows "how an individual becomes other than what he was". This is in line with the transformation of identities and teachers of this study too.

Moreover, the analysis of narratives showed that the teachers' discourse was linked to the outside cultural contexts intermingling a web of variables to work in the ever constructing, deconstructing and reconstructing of these identities. New identities are born as different versions of the self in a clash of different centripetal and centrifugal forces. The emergence of these identities depends both on the saliency of chronotopes and the kinds of discourses associated with them. Saliency of chronotopes are closely related and fused with discourses which result in the cyclic formation and reformation of identities. By saliency of chronotopes we mean those simultaneous critical moments and spaces which authoritatively lead to the imposed identities or are internally persuaded by the individuals continually. It is in fact the roles of these chronotopes that makes them different teachers acting in different ways.

There were, however, many authoritative blocks serving the dogmatic ideologies advocated by the external voices in the sometimes predictable and unpredictable routes of teachers' development of their multiple identities. And our final remark is that research on changes in teacher identity is a complex issue and time consuming. In Korthagen (2004) words, "fundamental changes in teacher identity do not take place easily: identity change is a difficult and sometimes painful process, and often there seems to be little change at all in how teachers view themselves" (p. 85).

We have tried to present the data as open and real as possible and the conclusions are also open-ended. The results can be compared, however, with a larger sample including many teachers both from public and private schools. The results can also be discussed in regard to other theories of teacher identity. Moreover, teachers identity is not separable from the whole context of teaching including learners' interaction, textbooks, and the place they are working and also all the societal factors which may play a role in teachers identity. To do such a research may sound to be difficult, but it gives us the understanding that identity is a complex issue.

\section{References}

Alsup, J. (2006). Teacher identity discourses: Negotiating personal and professional spaces. Mahwah, NJ: Lawrence Erlbaum.

Bakhtin, M. M. (1973). Problems of Dostoevsky's poetics. (R. W. Rotsel, Trans.). USA: Ardis. 
The chronotopical nature of identity construction: Case studies of narrative identities of EFL teachers

Bakhtin, M. M. (1981). Discourse in the novel. In M. Holquist (Ed.), The dialogic imagination (pp. 259-442). Austin: University of Texas Press.

Bakhtin, M. M. (1981). The dialogic imagination. Four essays by M. M. Bakhtin. USA: University of Texas Press Austin.

Bakhtin, M. M. (1986). The problem of speech genres. (V. W. McGee, Trans.). In C. Emerson \& M. Holquist (Eds.), M. M. Bakhtin: Speech genres and other late essays (pp. 60-102). Austin: University of Texas Press.

Bastos, L. C. \&, Oliveria, M. (2006). Identity and personal /institutional relations: People and tragedy in a health insurance customer service. In A. De Fina, D. Schiffrin, \& M. Bamberg (Eds.). Discourse and Identity (pp. 188 -212). Cambridge: Cambridge University Press. http://dx.doi.org/10.1017/CBO9780511584459.010

Bourdieu, P., \& Passeron, J. C. (1977). Reproduction in education, society and culture. (R. Nice \& T. Bottommore, Trans.). London: Sage.

Brandist, C. (1999). Review article: Bakhtinology and ideology. Dialogism: An International Journal of Bakhtin Studies, 2, 87-94.

Buty, C., \& Mortimer, E. F. (2008). Dialogic/authoritative discourse and modeling in a high school teaching sequence on optics. International Journal of Science Education, 30(12), 1635-1660. http://dx.doi.org/10.1080/09500690701466280

Clark, K., \& Holquist, M. (1984). Mikhail Bakhtin. Cambridge, MA: Harvard University Press.

Cohen, J. (2008). That's not treating you as a professional: Teachers constructing complex professional identities through talk. Teachers and Teaching: Theory and Practice, 14(2), 79-93. http://dx.doi.org/10.1080/13540600801965861

Connelly, M., \& Clandinin, J. (1999). Shaping a professional identity: Stories of educational practice. London, ON: The Althouse Press.

Cote, J. (2000). Bakhtin's dialogism reconsidered through Hegel's 'monologism': The dialectical foundation of aesthetics and ideology in contemporary human sciences. In C. Brandist \& G. Tihanov (Eds.), Materializing Bakhtin: The Bakhtin circle and social theory (pp. 20-42). London: MacMillan Press.

Delpit, L. (1995). Other people's children: Cultural conflict in the classroom. New York: New Press.

Emerson, C. (1997). The first hundred years of Mikhail Bakhtin. Princeton, NJ, Princeton University Press.

Flores, M. A., \& Day, C. (2006). Contexts which shape and reshape new teachers' identities: A multi-perspective study. Teaching and Teacher Education, 22(2), 219-232. http://dx.doi.org/10.1016/j.tate.2005.09.002

Gee, J. P. (1992). Sociolinguistics and literacies. New York: Falmer Press.

Gee, J. P. (1996). Social linguistics and literacies: Ideology in discourses (2nd ed.). Bristol, PA: Falmer Press.

Holquist, M. (1994). Dialogism. Bakhtin and his world. UK: Routledge.

Hunt, C. (2006). Travels with a turtle: Metaphors and the making of a professional identity. Reflective Practice, 7(3), 315-332. http://dx.doi.org/10.1080/14623940600837467

Johnston, B. (1997). Do EFL teachers have careers? TESOL Quarterly, 31(4), 681-712. http://dx.doi.org/10.2307/3587756

Korthagen, F. (2004). In search of the essence of a good teacher: Towards a more holistic approach in teacher education. Teaching and Teacher Education, 20, 77-97.

Matusov, E. (2007). Applying Bakhtin scholarship on discourse in education: A critical review essay. Educational Theory, 57(2), 215-237. http://dx.doi.org/10.1111/j.1741-5446.2007.00253.x

Menard-Warwick, J. (2011). Chilean English teacher identity and popular culture: Three generations. International Journal of Bilingual Education and Bilingualism, 14(3), 261-277. http://dx.doi.org/10.1080/13670051003797466

Mitchell, C., \& Weber, S. (1999). Reinventing ourselves as teachers: Beyond nostalgia. London: Routledge Falmer. http://dx.doi.org/10.4324/9780203454497

Morson, G., \& Emerson, C. (1990). Mikhail Bakhtin: The creation of a prosaics. Stanford: Stanford University Press.

Norton, B., \& Early, M. (2011). Researcher identity, narrative inquiry, and language teaching research, TESOL 
Hosseini Fatemi, A., Pishghadam, R., Hashemi, M. R., \& Adel, S. M. R.

Quarterly, 45(3), 415-439. http://dx.doi.org/10.5054/tq.2011.261161

Oliva, M. O. (2000). Shifting landscapes/Shifting langue: Qualitative research from the in between, Qualitative Inquiry, 6(33), 33-54. http://dx.doi.org/10.1177/107780040000600103

Pavlenko, A. (2002). Poststructuralist approaches to the study of social factors in second language learning and use. In V. Cook (Ed.), Portraits of the L2 User (pp. 277-302). Clevedon, UK: Multilingual Matters.

Pishghadam, R,. \& Shirmohammadi, S. (2012). Professional identity in Iran's higher education: A case of EFL professors. Journal of Educational and Social Research, 2(1), 317-328.

Pishghadam, R., \& Sadeghi, M. (2011). Culture and identity change among Iranian EFL teachers. Ozean Journal of Social Sciences, 4(12), 147-162.

Pishghadam, R., Hashemi, M. R., \& Adel, S. M. R. (2010). Dialogical interaction in formal and informal contexts: a study in an EFL situation. Iranian EFL Journal, 6(3), 27-71.

Razfar, A. (2012). Narrating beliefs: A language ideologies approach to teacher beliefs, Anthropology \& Education Quarterly, 43(1), 61-81. http://dx.doi.org/10.1111/j.1548-1492.2011.01157.x

Ricoeur, P. (1988). Time and narrative, volume 3 (K. Blamey \& D. Pellauer, Trans.). Chicago: University of Chicago Press.

Schiffrin, D. (1996). Narrative as self-portrait: Sociolinguistic constructions of identity. Language in Society, 25, 167- 203. http://dx.doi.org/10.1017/S0047404500020601

Schiffrin, D. (2006). In other words: variation in reference and narrative. Cambridge: Cambridge University Press. http://dx.doi.org/10.1017/CBO9780511616273

Sfard, A., \& Prusak, A. (2005). Telling identities: In search of an analytic tool for investigating learning as a culturally shaped activity. Educational Researcher, 34(4), 14-22. http://dx.doi.org/10.3102/0013189X034004014

Søreide, G. E. (2006). Narrative construction of teacher identity: Positioning and negotiation. Teachers and Teaching: Theory and Practice, 12(5), 527-547. http://dx.doi.org/10.1080/13540600600832247

Tihanov, G. (2000). The Master and the slave: Lukacs, Bakhtin, and the ideas of their time. Oxford and New York: Oxford University Press.

Tsui, A. B. M. (2007). Complexities of identity formation: A narrative inquiry of an EFL teacher. TESOL Quarterly, 41(4), 657- 680.

Varghese, M., Morgan, B., Johnston, B., \& Johnson, K. A. (2005). Theorizing language teacher identity: Three perspectives and beyond. Journal of Language, Identity \& Education, 4(1), 21-44. http://dx.doi.org/10.1207/s15327701jlie0401_2

Vitanova, G. (2005). Authoring the self in a non-native language: A dialogic approach to agency and subjectivity. In J. K. Hall, G. Vitanova, \& L. Marchenkova (Eds.), Dialogue with Bakhtin on second and foreign language learning: New perspectives (pp. 149-169). Mahwah, NJ: Lawrence Erlbaum. 